\title{
PROBLEM MENDASAR PENERAPAN \\ BEA PEROLEHAN HAK ATAS TANAH DAN/ATAU BANGUNAN
}

\author{
Achmad Faishal
}

Faculty of Law, Lambung Mangkurat of University

Email: achmad.faishal@ulm.ac.id

\begin{abstract}
Abstrak
Pentingnya artikel ini adalah untuk menunjukkan adanya problem mendasar dalam penerapan Bea Perolehan Hak Atas Tanah dan/atau Bangunan, Pertama, ditengah masyarakat terdapat suatu keadaan ketidaktahuan bahwa perolehan hak atas tanah dan/atau bangunan terkena kewajiban pajak, hal itu terjadi akibat ketiadaan informasi publik yang menjadi hak dari publik untuk mengetahuinya. Kedua, terjadi ketidakpastian hukum atas sebab nilai utang pajak muncul dari regresi dasar nilai perolehan yang bisa mengacu pada harga transaksi, harga pasar, atau nilai jual objek pajak bumi dan bangunan tahun perolehannya. Ketiga, perolehan hak atas tanah dipengaruhi oleh paradigma kekuatan hukum untuk dibuat dihadapan Notaris/PPAT setelah dilakukan pembayaran Bea Perolehan Hak Atas Tanah dan/atau Bangunan. Karena regresi dasar nilai perolehan objek pajak menimbulkan perbedaan nilai pajak maka Notaris/PPAT cenderung aktif mengarahkan para pihak untuk membuat nilai transaksi baru yang menguntungkan pihak yang memperoleh hak atas tanah dan/atau bangunan. Hukum di Indonesia tidak mengatur tindakan pejabat demikian sebagai suatu pelanggaran. Kondisi-kondisi tersebut dikemukakan dalam artikel ini secara dialektis sebagai respon terhadap tata hukum.
\end{abstract}

Kata Kunci: Pajak, Tanah, Bangunan, Informasi, dan Notaris/PPAT.

\section{Abstract}

The importance of this article is to show that the property tax in Indonesia, namely "Bea Perolehan Hak Atas Tanah dan/atau Bangunan" has a fundamental problem. This study finds the following: First, absence of public information which is the right of the public to know. Second, there is legal uncertainty because the tax debt value arises from the basic regression of the cost. The rules provide the option of using the sale and purchase transaction price or using the value that has been determined by the government regarding the price of land and/or buildings in a place namely "Nilai Jual Objek Pajak Bumi dan Bangunan". Third, the legality of obtaining property rights in Indonesia is influenced by the involvement of officials appointed by the government namely "Notaris/Pejabat Pembuat 
Akta Tanah". Officials can only authorize the transfer after the payment of property taxes. Because the basic regression of the acquisition value of tax objects creates differences in tax values, officials actively direct the parties to make new transaction values that benefit the parties who obtain rights to land and/or buildings. Indonesian law does not regulate such an official's actions as an offense. These conditions are presented in this article dialectically in response to regulation.

Keywords: Proverty, Tax, Information, and Notary.

\section{PENDAHULUAN}

\section{A. Latar Belakang}

Bea Perolehan Hak Atas Tanah (Selanjutnya disebut: BPHTB) memiliki sejumlah permasalahan yang aktual dan menarik untuk diperhatikan sehubungan aktifitas pemerintah dalam mengadministrasikan perolehan hak atas tanah dan/atau bangunan yang tidak lain adalah peristiwa hukum yang mengakibatkan diperolehnya hak atas tanah dan/atau bangunan oleh orang pribadi atau badan setelah melaksanakan kewajiban membayar BPHTB. ${ }^{1}$

Kewajiban membayar BPHTB, merupakan wewenang negara yang bersumber dari Pasal 33 ayat (3) yang menyatakan "Bumi dan air dan kekayaan alam yang terkandung di dalamnya dikuasai oleh negara dan dipergunakan untuk sebesar-besar kemakmuran rakyat." Kemudian oleh ayat (5) UUD 1945 menyatakan ketentuan lebih lanjut pelaksanaannya diatur dalam Undang-Undang.

Setelah diatur dalam Undang-Undang, ternyata secara implementatif penerapan kewajiban pajak BPHTB minim informasi yang diberikan kepada publik in haeren dengan masyarakat minim pemahaman dan pengetahuan tentang BPHTB. Di dalam masyarakat terdapat a) ketidaktahuan siapa yang menjadi subjek wajib bayar BPHTB, walaupun istilah "perolehan" menunjukkan bagi yang memperoleh dan untuk jual beli penjual menjadi subjek wajib pajak penghasilan, tetapi ditengah masyarakat masih terjadi antara penjual dan pembeli saling berkeras melimpahkan kewajiban dan kerap membayar secara urunan dimana pembeli menambah pembayaran dan/atau penjual mengurangkan nilai pembayaran. b) penyamaan persepsi BPHTB sama dengan Pajak Bumi dan Bangunan, dan c) merasa terpaksa atas besaran nilai pajak yang harus dibayar. Dalam persoalan demikian, masyarakat acapkali melimpahkan penyelesaiannya kepada Notaris/PPAT bangunan.

${ }^{1}$ BPHTB merupakan pajak yang dikenakan atas perolehan hak atas tanah dan/atau 
dengan meminta adanya penurunan nilai pajak yang mesti dibayar. Ditengah polemik demikian Notaris/PPAT yang juga tengah berada dalam persaingan keras untuk memperoleh klien kerap membangun sugesti dapat mengurangkan besaran pajak yang akan dibayar dengan cara menurunkan harga transaksi jual beli. Pertanyaan yang dapat diajukan adalah: Benarkah hal demikian dapat dilakukan dan tidak membawa akibat hukum bagi seorang Notaris/PPAT?

Selain minimnya informasi yang didapat oleh masyarakat, pengaturan BHTB dalam Undang-Undang Nomor 28 Tahun 2009 tentang Pajak Daerah dan Retrbusi Daerah (UUPDRD) permasalahan mendasarnya dapat dilihat dari ketentuan Pasal 87 yang menyatakan:

"(1) Dasar pengenaan Bea Perolehan Hak atas Tanah dan Bangunan adalah Nilai Perolehan Objek Pajak.

(2) Nilai Perolehan Objek Pajak sebagaimana dimaksud pada ayat (1), dalam hal:

a. jual beli adalah harga transaksi;

b. tukar menukar adalah nilai pasar;

c. hibah adalah nilai pasar;

d. hibah wasiat adalah nilai pasar;

e. waris adalah nilai pasar;

f. pemasukan dalam peseroan atau badan hukum lainnya adalah nilai pasar;

g. pemisahan hak yang mengakibatkan peralihan adalah nilai pasar;

h. peralihan hak karena pelaksanaan putusan hakim yang mempunyai kekuatan hukum tetap adalah nilai pasar;

i. pemberian hak baru atas tanah sebagai kelanjutan dari pelepasan hak adalah nilai pasar;

j. pemberian hak baru atas tanah di luar pelepasan hak adalah nilai pasar;

k. penggabungan usaha adalah nilai pasar;

1. peleburan usaha adalah nilai pasar;

m. pemekaran usaha adalah nilai pasar;

n. hadiah adalah nilai pasar; dan/atau

o. penunjukan pembeli dalam lelang adalah harga transaksi yang tercantum dalam risalah lelang.

(3) Jika Nilai Perolehan Objek Pajak sebagaimana dimaksud pada ayat (2) huruf a sampai dengan huruf $\mathrm{n}$ tidak diketahui atau lebih rendah daripada NJOP yang digunakan dalam pengenaan Pajak Bumi dan Bangunan pada tahun terjadinya perolehan, dasar pengenaan yang dipakai adalah NJOP Pajak Bumi dan Bangunan. 
(4) Besarnya Nilai Perolehan Objek Pajak Tidak Kena Pajak ditetapkan paling rendah sebesar Rp60.000.000,00 (enam puluh juta rupiah) untuk setiap Wajib Pajak.

(5) Dalam hal perolehan hak karena waris atau hibah wasiat yang diterima orang pribadi yang masih dalam hubungan keluarga sedarah dalam garis keturunan lurus satu derajat ke atas atau satu derajat ke bawah dengan pemberi hibah wasiat, termasuk suami/istri, Nilai Perolehan Objek Pajak Tidak Kena Pajak ditetapkan paling rendah sebesar Rp300.000.000,00 (tiga ratus juta rupiah). ${ }^{2}$

(6) Nilai Perolehan Objek Pajak Tidak Kena Pajak sebagaimana dimaksud pada ayat (4) dan ayat (5) ditetapkan dengan Peraturan Daerah." 3

Permasalahan Pasal 87 di atas, ada pada komponen dasar untuk menentukan Nilai Perolehan Objek Pajak berupa harga transaksi apabila perolehan melalui jual beli dan yang lainnya berupa nilai pasar. Jika "harga transaksi atau nilai pasar tidak diketahui atau lebih rendah daripada NJOP yang digunakan dalam pengenaan Pajak Bumi dan Bangunan pada tahun terjadinya perolehan, maka dasar pengenaan yang dipakai adalah NJOP Pajak Bumi dan Bangunan". ${ }^{4}$ Apabila dilakukan penghitungan yang terjadi adalah perbedaan besaran nilai pajak. Daripada itu orang akan lebih mencari yang menghasilkan nilai rendah. Hal tersebut juga didukung oleh prinsip perpajakan yang disebut Self Assesment yakni menghitung sendiri besaran kewajiban pajak. Prinsip demikian jelas tidak sinkron dengan asas kepastian hukum.

Ketidaksinkronan akibat aturan BPHTB memberikan pilihan dimana perolehan melalui jual beli dapat menggunakan harga transaksi atau NJOP PBB dan apabila selain jual beli dapat menggunakan nilai pasar atau NJOP $\mathrm{PBB}$, jika harga transaksi atau nilai pasar tidak diketahui atau lebih rendah

\footnotetext{
${ }^{2}$ Ketentuan ayat (5) ini sering diabaikan karena ketidaktahuan masyarakat tentang adanya margin ambang batas terendah tidak kena pajak dan perolehan karena waris atau hibah dalam keluarga sedarah tetap dikenakan BPHTB seperti umumnya.

${ }^{3}$ Lembaran Negara Republik Indonesia Tahun 2009 Nomor 130.

${ }^{4}$ Ketentuan Pasal 87 politik hukumnya adalah menarik investasi untuk percepatan pembangunan bahwa perolehan tanah melalui izin lokasi untuk peralihan hak tidaklah akan membebani investor. Politik hukum demikian adalah suatu hal yang realistis ditengah persaingan global negara berkembang, namun perlu ada solusi berupa pemilahan BPHTB antara kegiatan penanaman modal dengan BPHTB bagi masyarakat untuk kepemilikan tanah dan/atau bangunan untuk hunian dan/atau kegiatan usaha skala kecil menengah.
} 
dari NJOP PBB maka digunakan NJOP PBB yang pada kenyataannya NJOP PBB di daerah kabupaten/kota walaupun rata-rata telah mengatur tentang Pajak Bumi dan Bangunan namun pada kenyataannya di lapangan masih banyak ditemukan kondisi Bupati/Walikota hanya menetapkan klas NJOP sedang wilayah dan besaran nilainya tidak ditetapkan atau menetapkan tetapi tidak disesuaikan dengan perkembangan yang terjadi di lapangan. Dari keadaan demikian hukum menjadi tidak pasti.

Ketidakpastian tersebut menimbulkan pemufakatan menurunkan harga transaksi/nilai pasar setidaknya mendekati harga NJOP atau dipersamakan. Dari itu seorang Notaris/PPAT mengambil aksi membangun market berdasarkan Word of Mouth (WOM) atau diartikan dari mulut ke mulut yang mendatangkan input berharga atas seorang Notaris/PPAT tanpa biaya komunikasi terjadi dari mulut ke mulut bahwa "dia" memberikan harga jasa kompetitif, jelas ada buktinya seseorang yang mendapatkan akta perolehan hak atas tanah dan/atau bangunan dan itu dalam metode komunikasi dianggap jujur apa adanya karena norma Undang-Undang dalam kondisi ketidakpastian. Dimensi demikian disebut dengan istilah "regresi" dengan menempatkan Pasal 87 ayat (1) Jo. Ayat (2) huruf a berkedudukan sebagai variabel tetap dipengaruhi oleh ayat (3) yang merupakan variabel "penyebab" atau variabel independen.

\section{B. Landasan Pemikiran}

Penulisan artikel ini menempatkan teori dasar dalam perpajakan berupa teori kepentingan, teori pajak mutlak atau bakti, dan pada tataran implementasi menempatkan teori kepastian orientasi dari kepastian hukum.

Teori kepentingan bersumber pada pemikiran tentang hakikat bernegara, negara memerlukan adanya modal untuk berbagai pembiayaan dalam memenuhi kewajibannya. Teori ini menyatakan: "Perlindungan terhadap harta benda yang lebih banyak hartanya daripada harta si miskin, diharuskan pembayaran pajak yang lebih besar pula. ${ }^{5}$ Menurut R. Santoso Brotodihardjo:

"Teori ini dalam ajarannya yang semula, hanya memperhatikan pembagian beban pajak yang harus dipungut dari penduduk seluruhnya. Pembagian beban ini harus didasarkan atas kepentingan orang masing-masing dalam tugas-tugas pemerintahan (yang bermanfaat baginya), termasuk perlindungan atas jiwa orang-orang itu beserta harta bendanya. Maka sudah selayaknyalah bahwa biaya-

${ }^{5}$ Lihat: Brotodihardjo, R. Santoso, 2003, Pengantar Ilmu Hukum Pajak, Bandung: PT. Refika Aditama, h. 31. 
biaya yang dikeluarkan oleh negara untuk menunaikan kewajibannya, dibebankan kepada mereka itu."

Selanjutnya tentang teori kewajiban pajak mutlak atau bakti, teori ini mengajarkan kepentingan negara diatas segalanya berlandaskan paham Organische Staatsleer. Teori ini menyatakan:

"Negara memiliki sifat hak mutlak untuk memungut pajak. Orangorang tidak berdiri sendiri; dengan tidak adanya persekutuan, tidaklah ada individu. Oleh karenanya maka persekutuan itu (yang menjelma dalam negara) berhak atas suatu dan lain."

Menurut W.H. Van de Berge:

"Negara sebagai groepsverband (organisasi dari golongan) dengan memperhatikan syarat-syarat keadilan, bertugas menyelenggarakan kepentingan umum, dan karenanya dapat dan harus mengambil tindakan-tindakan dalam lapangan pajak." 8

Adapun teori kepastian orientasi dari kepastian hukum merupakan suatu bentuk pengandaian dari kepastian hukum. Menurut Zippelius:

"Hukum harus sedemikian jelas sehingga masyarakat dan hakim dapat berpedoman padanya. Itu berarti setiap istilah dalam hukum harus dirumuskan dengan terang dan tegas sehingga tak ada keraguraguan tentang tindakan apa yang dimaksud."9

Norma yang tidak jelas atau ambigu tidak memberikan kebaikan berupa kepastian hukum karena disorientasi dan menjadikannya sulit diinformasikan ke publik. Terjadi keadaan semacam tidak mendidik, norma yang mana yang mesti dipatuhi dan terkadang menimbulkan sisi negatif berupa ketidakadilan antar subjek hukum yang seharusnya mendapatkan perlakuan sama. Artinya bergantung pada itikad dari penguasa. Karena ketidakjelasan yang mesti digunakan akan dicurigai dan menyediakan kemungkinan bagi pejabat berkuasa untuk seenaknya. Hal ini sangat berbahaya seperti dilapangan perpajakan penerapannya akan memberikan keuntungan pada pihak yang memiliki hubungan dengan penguasa.

Selain mendasarkan pada pemikiran teoritis di atas, harus pula menekankan segi definisi/ konsep/proposisi pajak dan hukum pajak. Pemikiran ini dikemukakan karena adanya pengertian yang berbeda, hal ini acapkali kurang diperhatikan oleh kalangan akademisi. Dari sekian banyak ahli yang mengemukakan tentang pengertian pajak, yang praktis dan mudah dipahami, seperti pandangan Seligman, sebagai berikut:

${ }^{6}$ Loc.cit.

${ }^{7}$ Ibid., Hal. 35

${ }^{8}$ Ibid., Hal. 35-36.

${ }^{9}$ Dalam: Suseno, Franz Magnis, 2003, Etika Politik (Prinsip-Prinsip Moral Dasar Kenegaraan Modern), Jakarta: PT. Gramedia Pustaka, h. 80. 
"A tax is a a compulsory contribution from the person to the government to defray the expenses incurred in the common interest of all without reference to special benefits confereed". ${ }^{10}$ sebagai berikut:

Adapun Reichsabgabenordnung (RAO) memuat pendefinisian,

"Steuren sind einmaligen oder laufende Geldleistungen dia nicht eine Gegenleistung Fur eine besonder leistung darstellen und von einem Offentlichrechtlichen Gemeinwesen zur Erzielung von Einkunften allen auferlegt warden, bei denen der Tatverstand zuftriff, an den das Gezetz die Leistungsplicht knupft."11

Dalam khasanah keilmuan di Indonesia, beberapa ahli mengemukakan pengertian pajak seperti yang sangat di kenal yaitu Rochmat Soemitro, dalam pandangannya: "Pajak adalah peralihan kekayaan dari pihak rakyat kepada kas negara untuk membiayai pengeluaran rutin dan "surplus"-nya digunakan untuk "public saving" yang merupakan sumber utama untuk membiayai "public investmen". ${ }^{12}$

Selanjutnya PJA Adriani, dalam pandangannya:

"Pajak adalah iuran kepada negara (yang dapat dipaksakan) yang terutang oleh yang wajib membayarnya menurut peraturanperaturan, dengan tidak mendapat prestasi-kembali yang langsung dapat ditunjuk, dan yang gunanya adalah untuk membiayai pengeluaran-pengeluran umum berhubungan denan tugas negara untuk menyelenggarakan pemerintahan." 13

Pendapat PJA Adriani dengan menggunakan frasa "yang dapat dipaksakan" menunjukkan adanya kebijaksanaan seperti keringanan yang dapat diajukan oleh subjek yang terkena kewajiban. PJA Adriani nampaknya lebih responsif dalam memberikan pandangan bahwa tidak semua para wajib pajak berada dalam keadaan normal untuk mampu memenuhi kewajiban perpajakan.

Adapun pengertian "hukum pajak" jelas menempati pada refleksi yang berbeda dari pengertian pajak itu sendiri. Ketika sudah bersentuhan dengan

${ }^{10}$ Dalam: Ahmadi, Wiratni, 2006, Perlindungan Hukum Bagi Wajib Pajak Dalam Penyelesaian Sengketa Pajak, Bandung: PT. Refika Aditama, h. 6. Menterjemahkan: Pajak adalah suatu sumbangan paksaan dari perorangan kepada pemerintah untuk membiayai pengeluaran yang bertalian dengan kepentingan orang banyak (umum) tanpa dapat ditunjukkan adanya keuntungan khusus terhadapnya.

${ }^{11}$ Loc.cit. Diterjemahkan: Pajak-pajak adalah pembayaran (prestasi) uang sekaligus atau berulang-ulang yang tidak mempunyai suatu jasa timbal balik terhadap suatu jasa khusus dari rakyat, yang dipungut oleh suatu Badan Hukum Umum dari setiap orang, untuk memperoleh pendapatan, bila dipenuhi Tatbestand yang diwajibkan Undang-Undang.

${ }^{12}$ Soemitro, Rochmat, 1974, Pajak dan Pembangunan, Bandung: Eresco, h. 8.

${ }^{13}$ Ahmadi, Wiratni, Op.cit. Hal. 5. 
arti "hukum" maka pajak telah menempatkan diri kedalam tata pengaturan. Hal yang berkenaan dengan perintah, larangan, dan sanksi yang bersentuhan langsung dengan hak dasar setiap orang menempatkan aturan hukum berada dalam bentuk Undang-Undang atau produk legislasi (produk yang dihasilkan oleh rakyat dalam hal ini keterwakilannya oleh Dewan Perwakilan Rakyat), sehingga memunculkan analogi deskripsi pajak itu bukan kehendak negara semata karena negara butuh biaya untuk penyelenggaraannya melainkan kehendak rakyat sendiri untuk bernegara dengan memberikan sebagian kekayaannya guna terselenggaranya negara. Dalam konklusinya, pajak sebagai kontribusi wajib kepada negara yang terutang oleh orang pribadi atau badan yang bersifat memaksa berdasarkan Undang-Undang, dengan tidak mendapatkan imbalan secara langsung dan digunakan untuk keperluan negara/daerah bagi sebesar-besarnya kemakmuran rakyat.

\section{Pengaturan BPHTB}

Pembebanan kewajiban membayar pajak atas tanah dan bangunan, merupakan konsep hukum barat yang dibawa oleh kolonial Belanda ke Indonesia, tak terkecuali konsep $\mathrm{Bea}^{14}$ Balik Nama atas pemindahan harta atau yang dikenal BPHTB dimana kolonial Belanda melakukan pengaturannya berupa Staatsblad 1924 Nomor 291 bahwa pemindahan harta dikenakan pungutan Bea Balik Nama. Masuk ke pasca kemerdekaan dimana Negara Republik Indonesia adalah negara hukum berdasarkan Pancasila dan UUD 1945, terhadap keberadaan Staatsblad 1924 Nomor 291 tetaplah diberlakukan. ${ }^{15}$ Walaupun lahir produk legislasi Indonesia di bidang

${ }^{14}$ Bea memiliki pengertian sama dengan pengertian pajak. Penggunaan istilah Bea ditujukan pada jenis pajak yang dikenakan secara insidentil atas adanya perolehan hak dimana negara memberikan pengakuan atas perolehan hak tersebut. Seperti barang impor, negara memberikan pengakuan untuk hak kepemilikan bagi pengimpor atau yang membawa masuk barang tersebut kedalam wilayah Indonesia apabila yang bersangkutan telah memenuhi kewajiban membayar pajak yang disebut bea masuk barang berdasarkan penetapan Pemerintah atas barang-barang yang terkena bea masuk. Sedang atas tanah dan bangunan dibebankan perolehannya pajak pula yang disebut bea karena adanya perolehan hak yang hanya akan diakui negara diantara pengakuan tersebut dengan membayar kewajiban pajak. Termasuk perikatan antara para pihak yang salah satu atau diantaranya diuntungkan dari perikatan itu, negara turut hadir dengan memberikan kewajiban kepada para pihak untuk membayar bea materai atas perikatan dimaksud sebagai dasar bahwa perikatan tersebut bersandarkan pada peran negara dan apabila dikemudian hari terjadi suatu persoalan yang mesti diselesaikan melalui peran negara.

${ }^{15}$ Dimasa itu disebut dengan istilah menghindari kehampaan hukum. Istilah itu sekarang dipopulerkan dengan sebutan menghindari kekosongan hukum (vacum by norm). 
pertanahan yakni Undang-Undang Nomor 5 Tahun 1960 tentang PokokPokok Agraria yang menghapuskan keberadaan aturan-aturan kolonial di bidang pertanahanan, meliputi:

1. "Agrarische Wet" (Staatsblad 1870 No. 55) sebagai yang termuat dalam pasal 51 "Wet op de Staatsinrichting van Nederlands Indie" (Staatsblad 1925 No. 447) dan ketentuan dalam ayat-ayat lainnya dari pasal itu;

2. a. "Domeinverklaring" tersebut dalam pasal 1 "Agrarisch Besluit" (Staatsblad 1870 No. 118);

b. "Algemene Domeinverklaring" tersebut dalam Staatsblad 1875 No. 119A;

c. "Domeinverklaring untuk Sumatera" tersebut dalam pasal 1 dari Staatsblad 1874 No. 94f;

d. "Domeinverklaring untuk keresidenan Menado" tersebut dalam pasal 1 dari Staatsblad 1877 No. 55;

e. "Domeinverklaring untuk residentie Zuider en Oosterafdeling van Borneo" tersebut dalam pasal 1 dari Staatsblad 1888 No. 58;

3. Koninklijk Besluit tanggal 16 April 1872 No. 29 (Staatsblad 1872 No. 117) dan peraturan pelaksanaannya; dan

4. Buku ke-II Kitab Undang-Undang Hukum Perdata Indonesia sepanjang yang mengenai bumi, air serta kekayaan alam yang terkandung di dalamnya, kecuali ketentuan-ketentuan mengenai hypotheek yang masih berlaku pada mulai berlakunya Undangundang ini. ${ }^{16}$

Penghapusan di atas tidaklah memuat Staatsblad 1924 Nomor 291. Selama 37 (tiga puluh tujuh) tahun kedepannya baru dibentuk UndangUndang Nomor 21 Tahun 1997 tentang Bea Perolehan Hak Atas Tanah dan Bangunan yang melakukan pencabutan dengan menyatakan:

"Dengan berlakunya Undang-Undang ini, Ordonansi Bea Balik Nama Staatsblad 1924 Nomor 291 dengan segala perubahannya sepanjang mengenai pungutan Bea Balik Nama atas pemindahan harta tetap yang berupa tanah dan atau bangunan, dinyatakan tidak berlaku." (Vide; Pasal 27).

Eksistensi Undang-Undang Nomor 21 Tahun 1997, ternyata dianggap tidak memberikan kepastian hukum. Hal itu melandasi terjadinya perubahan atas Undang-Undang Nomor 21 Tahun 1997 dengan ditetapkannya Undang-Undang Nomor 20 Tahun 2000 tentang Perubahan Atas Undang-Undang Nomor 21 Tahun 1997 tentang Bea Perolehan Hak Atas Tanah dan Bangunan. Pertimbangannya:

${ }^{16}$ Lembaran Negara Tahun 1960 Nomor 104. 
"Bahwa dalam rangka lebih meningkatkan kepastian hukum dan keadilan, serta menciptakan sistem perpajakan yang sederhana dengan tanpa mengabaikan pengawasan dan pengamanan penerimaan negara agar pembangunan nasional dapat dilaksanakan secara mandiri dan untuk menampung penyelenggaraan kegiatan usaha yang terus berkembang di bidang perolehan hak atas tanah dan bangunan, perlu dilakukan perubahan terhadap Undang-undang Nomor 21 Tahun 1997 tentang Bea Perolehan Hak atas Tanah dan Bangunan". ${ }^{17}$

Dari sejarah pengaturan di atas, dapatlah diketahui eksistensi pemungutan pajak atas perolehan harta (tanah dan bangunan) memang ada sejak masa kolonial hingga sekarang dengan konsep yang tetap sama, yakni:

"bahwa terhadap orang pribadi atau badan yang memperoleh hak atas tanah dan atau bangunan, berdasarkan peraturan perundangundangan yang berlaku perlu dikenakan pajak dengan nama Bea Perolehan Hak atas Tanah dan Bangunan".

Masih digunakannya konsep hukum barat dilandasi pemikiran di ranah filosofis "bahwa Negara Republik Indonesia adalah Negara hukum berdasarkan Pancasila dan UUD 1945, dalam perkembangannya telah menghasilkan pembangunan yang pesat dalam kehidupan nasional yang perlu dilanjutkan dengan dukungan Pemerintah dan seluruh potensi masyarakat, karena itu menempatkan perpajakan sebagai salah satu perwujudan kewajiban kenegaraan yang merupakan sarana peran serta dalam pembiayaan Negara dan pembangunan nasional". Di ranah sosiologis, dilandasi pemikiran: "bahwa baik tanah yang mempunyai fungsi sosial sebagai karunia Tuhan Yang Maha Esa maupun bangunan memberikan keuntungan dan atau kedudukan sosial ekonomi yang lebih baik bagi orang pribadi atau badan yang memperoleh suatu hak atasnya, oleh karena itu wajar bila mereka yang memperoleh hak atas tanah dan atau bangunan diwajibkan membayar pajak kepada Negara".

Pengaturan BPHTB sekarang, struktur hukumnya diawali pada tingkatan hukum dasar yakni Undang-Undang Dasar Negara Republik Indonesia Tahun 1945, dalam Pasal 23A menyatakan "Pajak dan pungutan lain yang bersifat memaksa untuk keperluan negara diatur dengan undangundang."18 Selanjutnya Pemerintah mengambil kebijakan melimpahkan

${ }^{17}$ Lembaran Negara Repubik Indonesia Tahun 2000 Nomor 130.

${ }^{18}$ Tafsir yang dapat dikemukakan bahwa negara dengan kekuasaannya menerapkan kewajiban pajak kepada setiap orang dengan legitimasi etis mengaturnya dalam suatu undang-undang agar daya paksa itu mengikat secara umum dengan penerapannya dilakukan oleh Pemerintah yang tentunya juga akan mengeluarkan sejumlah aturan pelaksanaan dari undang-undang. Rasio yang dibangun atas kewajiban pajak adalah terselenggaranya 
kewenangan pemungutan pajak BPHTB kepada Pemerintah Kabupaten/Kota. Hal itu direalisasikan dengan menetapkan UndangUndang Nomor 28 Tahun 2009 tentang Pajak Daerah dan Retribusi Daerah (UUPDRD). Kehadiran UUPDRD adalah mencabut dan menyatakan tidak berlaku lagi terhadap Undang-Undang Nomor 21 Tahun 1997 tentang Bea Perolehan Hak atas Tanah dan Bangunan sebagaimana diubah dengan Undang-Undang Nomor 20 Tahun 2000 tentang Perubahan atas UndangUndang Nomor 21 Tahun 1997 tentang Bea Perolehan Hak atas Tanah dan Bangunan.

\section{PEMBAHASAN}

\subsection{Hubungan Informasi Publik dengan BPHTB}

Dalam sebuah negara demokrasi, pemilik kekuasaan tertinggi adalah rakyat kepada siapa Pemerintah mempertanggungjawabkan akuntabilitasnya. Akuntabilitas diantaranya adalah perihal pajak yang dipungut oleh negara melalui badan Pemerintah. Masyarakat berhak mengetahui tentang adanya kewajiban perpajakan diantaranya pajak perolehan hak atas tanah dan/atau bangunan, karena merupakan hak dasar sebagaimana diatur dalam Undang-Undang Dasar Negara Kesatuan Republik Indonesia Tahun 1945 (UUD 1945), pada Pasal 28F mengenai hak "memperoleh informasi". Pasal 28F menyatakan:

"Setiap orang berhak untuk berkomunikasi dan memperoleh informasi untuk mengembangkan pribadi dan lingkungan sosialnya; serta berhak untuk mencari, memperoleh, memiliki, menyimpan, mengolah dan menyampaikan informasi dengan menggunakan segala jenis saluran yang tersedia."

Menurut ICEL "Gagasan utama hak atas informasi adalah bahwa informasi yang dikuasai oleh Badan Publik tidaklah dimiliki oleh mereka, akan tetapi dikuasai atas nama rakyat, dan bahwa rakyat harus memiliki akses terhadap informasi, dengan pengecualian secara terbatas untuk melindung kepentingan yang lebih tinggi."19

Selanjutnya, ICEL juga mengemukakan pengelolaan dan penyelenggaraan keterbukaan informasi publik secara baik dan benar dapat memberikan beberapa keuntungan praktis bagi badan publik dan kepada bangsa secara keseluruhan antara lain sebagai berikut:

"1. Menginformasikan opini publik melalui informasi yang akurat.

pemungutan untuk kemudian menyerahkannya kembali kepada masyarakat dalam bentuk anggaran belanja negara dan daerah.

${ }^{19}$ Indonesian Center For Environmental Law. (tt) Modul Bagi Badan Publik. Melaksanakan Undang-Undang Nomor 14 Tahun 2008 Tentang Keterbukaan Informasi Publik., h. 4 
2. Informasi publik yang akurat dapat mencegah rumor negatif dan tidak benar beredar.

3. Meminimalisir Korupsi dan Penyalahgunaan Informasi Orang Dalam.

4. Memperbaiki Kinerja Badan Publik secara Lebih Tepat.

5. Membangun hubungan baik dan meningkatkan Kepercayaan Publik terhadap Badan Publik.

6. Akuntabilitas demokratis."20

Dalam eskalasi dunia, hak atas informasi juga dilindungi dengan penuangannya ke dalam Artikel 19 International Covenant on Civil and Political Rights, yang telah diadopsi oleh 167 negara termasuk Indonesia. Menurut PBB, OAS, dan OSCE:

"Implisit dalam kebebasan berekspresi adalah hak publik terhadap akses informasi yang terbuka dan untuk mengetahui apa yang sedang dilakukan pemerintah atas nama mereka, dimana tanpanya kebenaran akan menghilang dan partisipasi rakyat dalam Pemerintahan akan tetap terfragmentasi". ${ }^{21}$

Selain itu, terdapat pula berbagai inisiatif global, yang paling signifikan menamakan diri Open Government Partnership (OGP) yang membuat komitmen nyata dan kuat dari pemerintah untuk aktif mendorong transparansi, meningkatkan partisipasi masyarakat luas, memberantas korupsi dan memanfaatkan teknologi-teknologi terkini untuk membuat pemerintah lebih terbuka, efektif dan akuntabel. ${ }^{22}$

Pada umumnya, negara di dunia telah memiliki legislasi setingkat undang-undang terkait hak atas informasi yang secara umum mengatur perlindungan terhadap hak atas informasi dan prosedur bagi publik untuk meminta dan menerima informasi. ${ }^{23}$ Indonesia sebagai negara aktif dalam meratifikasi hak asasi manusia diantaranya International Covenant on Civil and Political Rights, mengatur tentang informasi publik melalui sebuah produk legislasi yakni Undang-Undang Nomor 14 Tahun 2008 tentang Keterbukaan Informasi Publik (UU KIP).

Pasal 1 angka 1 UU KIP menyatakan:

"Informasi adalah keterangan, pernyataan, gagasan, dan tanda-tanda yang mengandung nilai, makna dan pesan, baik data, fakta maupun penjelasannya yang dapat dilihat, didengar, dan dibaca yang

${ }^{20}$ Ibid. Hal. 4-5.

${ }^{21}$ Ibid. Hal. 6

${ }^{22}$ Lihat: Open Government Partnership, Participating Countries, Dalam: http://www. opengovpartnership.org/countries.

${ }^{23}$ Lihat: Open Society Justice Initiatives, Access to Information Laws: Overview and Statutory Goals. Dalam: http://right2info.org/access-to-information-laws. 
disajikan dalam berbagai kemasan dan format sesuai dengan perkembangan teknologi informasi dan komunikasi secara elektronik ataupun non-elektronik."24

Pasal 1 angka 2

"Informasi Publik adalah informasi yang dihasilkan, disimpan, dikelola, dikirim, dan/atau diterima oleh suatu Badan Publik yang berkaitan dengan penyelenggara dan penyelenggaraan negara dan/atau penyelenggara dan penyelenggaraan Badan Publik lainnya yang sesuai dengan Undang-Undang ini serta informasi lain yang berkaitan dengan kepentingan publik." $" 25$

Hal yang mendasar dalam penyelenggaraan BPHTB pada prinsipnya merupakan keterbukaan informasi publik, karena tanpa melakukan hal demikian minimnya informasi BPHTB telah membangun stigma negatif penyelenggaraannya sebagai bentuk yang ekslusif, tidak transparan, hingga menjadi ajang permainan kepentingan.

Pertanyaan yang dapat diajukan adalah: Apakah BPHTB harus diinformasikan ke publik? BPHTB yang berada dalam tataran norma Undang-Undang dalam aturan ketatanegaraan sebuah Undang-Undang yang telah disepakati oleh Dewan Perwakilan Rakyat bersama Presiden dan disahkan oleh Presiden dan selanjutnya ditetapkan Pemerintah akan selalu diiringi dengan tindakan pemuatannya dalam lembaran negara. Ketentuan penutup dari sebuah Undang-Undang memuat kalimat: "Agar setiap orang mengetahuinya, memerintahkan pengundangan Undang-Undang ini dengan penempatannya dalam Lembaran Negara Republik Indonesia." Artinya, dengan frasa "agar setiap orang mengetahuinya" maka ketentuan yang telah diatur dalam Undang-Undang telah dianggap semua orang mengetahuinya. Maka dari itu sosialisasi berada dalam tahapan rancangan sebuah UndangUndang atau tidak pada tahapan implementasinya. Daripada itu dibutuhkan kebijaksanaan (wisdom) dari Pemerintah untuk memperjelas hakiki dari sebuah norma dalam Undang-Undang karena tidak setiap orang dapat memahami isi dari sebuah Undang-Undang yang mengikat kepadanya. Sedang dalam tataran implementasi, ketika sebuah norma yang mengikat secara umum dianggap meresahkan dan menimbulkan berbagai aspek negatif maka yang dibutuhkan adalah tentang ratio legis.

Dapat dibentuknya suatu peraturan perundang-undangan tidak serta merta bahwa peraturan perundang-undangan tersebut dapat diimplementasikan dengan baik, karena hal ini tidak terlepas dari adanya beragam faktor yang dapat mempengaruhinya. Di satu pihak peraturan

${ }^{24}$ Lembaran Negara Republik Indonesia Tahun 2008 Nomor 61.

${ }^{25}$ Loc.cit. 
perundang-undangan berada pada tataran yang ideal, sedang implementasi berada pada tataran yang realistik. Di alam nyata (empirik), apa yang ideal tidaklah selalu menjadi realistik, atau apa yang menjadi seharusnya (das Sollen) tidaklah selalu demikian dengan apa yang menjadi senyatanya (das Sein).

Pada intinya, pengaturan di bidang perpajakan untuk skala norma Undang-Undang sangatlah minim diinformasikan ke publik, informasi yang dominan diberikan ke publik hanya pada kewajiban pembayaran berikut untuk ketaatan membayar melalui pamplet atau sebaran baleho bahkan bernuansa kepentingan politis penguasa daerah bahwa kepemimpinan daerah atas dukungan masyarakat, sedang asal usul kewajiban dan bagaimana perolehan nilai untuk dibayarkan masyarakat jauh dari pemahamannya.

Pada hakikatnya, relevansi hubungan antara BPHTB dengan informasi publik tidaklah dapat dipisahkan, karena sifat dasarnya adalah peran aktif dari masyarakat untuk turut serta membangun daerah melalui pajak yang dibayarkannya. Hal yang mendasar pula, bahwa banyaknya informasi publik yang dikuasai suatu Badan Publik, maka dalam pengelolaannya dibutuhkan pendokumentasian yang baik dan kejelasan mengenai informasi mana yang bersifat terbuka dan yang dikecualikan. Hal ini penting, mengingat perubahan paradigma dari "informasi tertutup" menjadi "informasi terbuka" di era keterbukaan informasi publik yang menuntut kejelasan mengenai informasi yang wajib untuk diumumkan dan disediakan serta bagaimana cara penyediaan dan pengumumannya. Disinilah titik penting pengkategorian informasi publik dalam menyelenggarakan keterbukaan informasi publik.

yaitu:

UU KIP mengelompokkan informasi publik dalam lima kategori,

1. Informasi publik yang wajib disediakan dan diumumkan secara berkala;

2. Informasi publik yang wajib diumumkan secara serta merta;

3. Informasi publik yang wajib tersedia setiap saat;

4. Informasi publik atas permintaan; dan

5. Informasi publik yang dikecualikan.

Pada kategori ke-5 di atas tidak dinyatakan secara eksplisit, akan tetapi dijelaskan di Pasal 52 UU KIP, yaitu "informasi publik yang wajib diberikan berdasarkan permohonan sebagaimana ditentukan dalam perundang-undangan ini". ${ }^{26}$ Dari kategori informasi di atas, pengkategorian informasi publik dapat dipersempit dalam 3 kategori besar, yaitu yang wajib diumumkan (secara berkala dan secara serta merta), wajib disediakan

${ }^{26}$ Lihat: Lembaran Negara Republik Indonesia Tahun 2008 Nomor 61 
(tersedia setiap saat dan atas dasar permintaan), dan informasi yang dikecualikan. ${ }^{27}$

Menjawab pertanyaan, Apakah BPHTB harus diinformasikan ke publik? Mengacu pada Pasal Pasal 11 UU KIP jo. Pasal 13 Peraturan Komisi Informasi Nomor 1 Tahun 2010 tentang Standar Layanan Informasi Publik, sebagai berikut:

Pasal 11

(1) Badan Publik wajib menyediakan Informasi Publik setiap saat yang meliputi:

a. daftar seluruh Informasi Publik yang berada di bawah penguasaannya, tidak termasuk informasi yang dikecualikan;

b. hasil keputusan Badan Publik dan pertimbangannya;

c. seluruh kebijakan yang ada berikut dokumen pendukungnya;

d. .... Dst.

\section{Pasal 13}

Setiap Badan Publik wajib menyediakan Informasi Publik setiap saat yang sekurangkurangnya terdiri atas:

a.

b. informasi tentang peraturan, keputusan dan/atau atau kebijakan Badan Publik yang sekurang-kurangnya terdiri atas:

1. dokumen pendukung seperti naskah akademis, kajian atau pertimbangan yang mendasari terbitnya peraturan, keputusan atau kebijakan tersebut;

2. masukan-masukan dari berbagai pihak atas peraturan, keputusan atau kebijakan tersebut;

3. risalah rapat dari proses pembentukan peraturan, keputusan atau kebijakan tersebut;

4. rancangan peraturan, keputusan atau kebijakan tersebut;

5. tahap perumusan peraturan, keputusan atau kebijakan tersebut; dan

6. peraturan, keputusan dan/atau kebijakan yang telah diterbitkan.

Apabila mengacu pada ketentuan Pasal 13 huruf b angka 6 di atas, tafsirannya untuk BPHTB menjadi jelas dimana BPHTB yang menjadi kewenangan Pemerintah Kabupaten/Kota untuk memungutnya melahirkan suatu kewajiban bagi Pemerintah Daerah Kabupaten/Kota untuk membuat aturan yakni Peraturan Daerah Tentang Bea Perolehan Hak Atas Tanah dan

27 Saragih, Alamsyah, 2012, Pengecualian Informasi di Badan Publik Negara, Komisi Informasi Pusat, Jakarta: h. 18. 
Bangunan. Dengan adanya Peraturan Daerah yang telah diterbitkan otomatis terkena kewajiban bagi Pemerintah Daerah setempat atas ketentuan Pasal 13 huruf b angka 6. Dengan demikian telah diperoleh jawaban bahwa BPHTB tidak lagi harus melainkan suatu kewajiban bagi Pemerintah Daerah Kabupaten/Kota untuk menginformasikannya kepada publik.

Dengan masuknya kedalam kategori informasi yang wajib tersedia setiap saat, dimana secara definisi memiliki pengertian "adalah informasi yang harus disediakan oleh Badan Publik dan siap tersedia untuk bisa langsung diberikan kepada Pemohon Informasi Publik ketika terdapat permohonan terhadap Informasi Publik tersebut". Disinilah ternyata problem BPHTB tidak diinformasikan kepada publik, sifatnya hanya akan diberikan atas permohonan dari yang berkepentingan sehingga BPHTB menjadi tidak familiar dalam pengetahuan publik. Apabila dipahami dengan menggunakan prinsip "Lex Stricta", bahwa setiap aturan harus ditafsirkan secara ketat, artinya interpretasi gramatikal memegang peran yang utama sebagaimana yang tertulis dalam aturan tersebut, maka frasa informasi yang wajib tersedia setiap saat dapat ditafsirkan secara gramatikal mengandung makna "Informasi yang wajib tersedia setiap saat disediakan dan diberikan kepada publik ketika terdapat permintaan atas informasi tersebut. Namun, tidak menutup kemungkinan bagi Badan Publik untuk lebih proaktif mengumumkan beberapa Informasi yang Wajib Tersedia Setiap Saat kepada publik apabila ada sarana yang memadai seperti situs resmi. Tindakan proaktif ini akan mengurangi beban badan publik sendiri untuk menjawab setiap permohonan Informasi Publik yang masuk." Artinya tidaklah rigid, dimana badan publik memiliki pula kewajiban menginformasikan tanpa adanya permintaan atas informasi tersebut. Dengan demikian maka sudah semestinya BPHTB di informasikan kepada publik tidak hanya mengenai beban kewajiban pajak tetapi harus pula pada bagaimana nilai yang harus dibayar oleh wajib pajak.

Dalam eskalasi informasi BPHTB ada kemungkinan keenganan pejabat publik menginformasikan secara detail bagaimana perolehan nilai objek pajaknya disebabkan kerumitan tata cara perhitungan sehingga sulit melakukan penyederhanaan bahasa, hal itu menjadi suatu tantangan yang perlu diatasi Badan Publik dalam menyampaikan informasi kepada masyarakat. Tidak jarang dokumen yang dikuasai badan publik disediakan mentah-mentah dalam bentuk aslinya yang terkadang hanya dapat dibaca oleh mereka yang memiliki pengetahuan dan keterampilan teknis tertentu. Seperti BPHTB, maka hanya Perda yang akan diberikan kepada yang memintanya sedangkan tatacara perhitungan tidaklah diketahui oleh publik. Dari itu sudah seharusnya badan publik yang diberi tugas dan kewenangan memungutnya membuatkan petunjuk tata cara perhitungan seperti yang 
dilakukan oleh Direktorat Jenderal Pajak untuk pajak berskala nasional yang sifatnya umum seperti Pajak Penghasilan walaupun juga sulit dipahami oleh masyarakat secara umum ketika mereka membuat petunjuk itu rumit dan terlalu banyak menggunakan bahasa yang tidak familiar.

\subsection{Regresi Dasar Nilai Perolehan Objek Pajak BPHTB}

Berdasarkan UUPDRD Nilai Jual Objek Pajak (NJOP) adalah harga rata-rata yang diperoleh dari transaksi jual beli yang terjadi secara wajar, dan bilamana tidak terdapat transaksi jual beli, NJOP ditentukan melalui perbandingan harga dengan objek lain yang sejenis, atau nilai perolehan baru, atau NJOP pengganti (Vide; Pasal 1 angka 40). Dalam eskalasinya, disebabkan perolehan hak atas tanah dan/atau bangunan sumbernya tidaklah satu bentuk melainkan beberapa bentuk, maka terjadi perbedaan. Harga transaksi maupun nilai pasar selain dari bentuk perolehan yang berasal dari penunjukkan pembeli dalam lelang "bisa tidak diketahui" baik memang terjadi secara nyata atau para pihak tidak ingin diketahui. Oleh pembentuk Undang-Undang dipasang klausa pengaman:

Jika:

a. Nilai Perolehan Objek Pajak tidak diketahui; atau

b. Nilai Perolehan Objek Pajak lebih rendah daripada NJOP yang digunakan dalam pengenaan Pajak Bumi dan Bangunan pada tahun terjadinya perolehan,

Dasar pengenaan yang dipakai adalah: NJOP Pajak Bumi dan Bangunan.

Klausa pengaman tersebut dapat ditafsirkan:

1. Untuk jual beli berdasarkan harga transaksi, bisa jadi waktu jual beli itu tidaklah ada perhitungan nyata dimana pembeli membayar dengan barang yang dianggap senilai dengan harga tanah dan/atau bangunan dan dikemudian hari para waris sudah tidak tahu berapa harga transaksinya.

2. Untuk bentuk yang berdasarkan nilai pasar, bisa jadi hal ini tidak relevan karena lokasi tanah dan/atau bangunan dianggap tidak strategis atau sebaliknya yang berpengaruh pada nilai jual tanah dan/atau bangunan dan nilai pasar itu sulit ditemukan.

Apabila dicermati, klausa pengaman tersebut ternyata menimbulkan kelemahan fundamental dimana para pihak dapat menciptakan suatu keadaan untuk menghindari pembayaran pajak yang besar. Kondisi demikian disebut dengan ambiguitas norm atau tidak tegas karena mengandung pilihan. Pertanyaan yang dapat diajukan, Mengapa tidak digunakan NJOP Pajak Bumi dan Bangunan saja yang jelas ditetapkan oleh Pemerintah Daerah setempat melalui Peraturan Daerah. 
NJOP Pajak Bumi dan Bangunan, terstruktur pemahamannya sebagai berikut:

1. Penetapan NJOP dapat dilakukan dengan:

a. perbandingan harga dengan objek lain yang sejenis, adalah suatu pendekatan/metode penentuan nilai jual suatu objek pajak dengan cara membandingkannya dengan objek pajak lain yang sejenis yang letaknya berdekatan dan fungsinya sama dan telah diketahui harga jualnya.

b. nilai perolehan baru, adalah suatu pendekatan/metode penentuan nilai jual suatu objek pajak dengan cara menghitung seluruh biaya yang dikeluarkan untuk memperoleh objek tersebut pada saat penilaian dilakukan, yang dikurangi dengan penyusutan berdasarkan kondisi pisik objek tersebut.

c. nilai jual pengganti, adalah suatu pendekatan/metode penentuan nilai jual suatu objek pajak yang berdasarkan pada hasil produksi objek pajak tersebut.

2. Pada dasarnya penetapan NJOP adalah 3 (tiga) tahun sekali. Untuk Daerah tertentu yang perkembangan pembangunannya mengakibatkan kenaikan NJOP yang cukup besar, maka penetapan NJOP dapat ditetapkan setahun sekali.

3. Nilai jual untuk bangunan sebelum diterapkan tarif pajak dikurangi terlebih dahulu dengan Nilai Jual Tidak Kena Pajak sebesar Rp.10.000.000,- (sepuluh juta rupiah).

Contoh tata perhitungan:

\begin{tabular}{|c|c|c|}
\hline \multicolumn{3}{|c|}{ Objek Pajak } \\
\hline Objek & Luas/Panjang & Harga/Nilai Jual Rp. \\
\hline Tanah & $800 \mathrm{~m} 2$ & $300.000,00 / \mathrm{m} 2$ \\
\hline Bangunan & $400 \mathrm{~m} 2$ & $350.000,00 / \mathrm{m} 2$ \\
\hline Taman & $200 \mathrm{~m} 2$ & $50.000,00 / \mathrm{m} 2$ \\
\hline $\begin{array}{l}\text { Panjang dan Tinggi } \\
\text { Pagar }\end{array}$ & $120 \mathrm{~m}$, Rerata $1,5 \mathrm{~m}$ & $175.000 / \mathrm{m} 2$ \\
\hline \multicolumn{3}{|c|}{ NJOP } \\
\hline Rumus & Perkalian & $\begin{array}{l}\text { Pokok Pajak } \\
\text { Terutang Rp. }\end{array}$ \\
\hline \multicolumn{3}{|l|}{ NJOP Bumi } \\
\hline Luas Tanah x Harga Jual & $800 x R p .300 .000,00$ & $240.000 .000,00$ \\
\hline \multicolumn{2}{|c|}{ Nilai Jual Tanah Kena Pajak } & $240.000 .000,00$ \\
\hline \multicolumn{3}{|c|}{ NJOP Bangunan Rumah dan Garasi } \\
\hline $\begin{array}{l}\text { Luas Bangunan x Nilai } \\
\text { Jual }\end{array}$ & 400xRp.350.000,00 & $140.000 .000,00$ \\
\hline \multicolumn{3}{|l|}{ NJOP Tamah } \\
\hline Luas Taman x Nilai Jual & 200xRp.50.000,00 & $10.000 .000,00$ \\
\hline NJOP Pagar & & \\
\hline
\end{tabular}




\begin{tabular}{|c|c|}
\hline 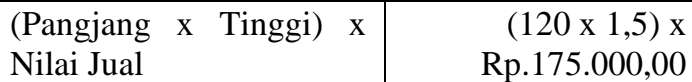 & $31.500 .000,00$ \\
\hline NJOP Bangunan & $181.500 .000,00$ \\
\hline Nilai Jual Objek Pajak Tidak Kena Pajak & $10.000 .000,00$ \\
\hline Nilai Jual Bangunan Kena Pajak & 171.500.000,00 \\
\hline Nilai Jual Objek Pajak Kena Pajak & 411.500.000,00 \\
\hline $\begin{array}{r}\text { Tarif Pajak Efektif yang Ditetapkan Dalam } \\
\text { Peraturan Daerah }\end{array}$ & $0,2 \%$ \\
\hline $\begin{array}{r}\text { PBB Terutang } \\
0,2 \% \times \mathrm{Rp} 411.500 .000,00\end{array}$ & 823.000,00 \\
\hline
\end{tabular}

Sumber: Tambahan Lembaran Negara Republik Indonesia Nomor 5049

Dari tata perhitungan di atas, apabila diperbandingkan dengan tata perhitungan BPHTB berdasarkan harga transaksi atau nilai pasar sebagaimana Penjelasan dalam UUPDRD:

Wajib Pajak "A" membeli tanah dan bangunan dengan:

Nilai Perolehan Objek Pajak = Rp65.000.000,00

Nilai Perolehan Objek Pajak Tidak Kena Pajak

Nilai Perolehan Objek Pajak Kena Pajak

$$
=\text { Rp60.000.000,00 (-) }
$$

$$
=\operatorname{Rp} 5.000 .000,00
$$

Pajak Yang Terutang $=5 \% \times$ Rp5.000.000,00

$$
=\operatorname{Rp} 250.000,00
$$

Dengan Persamaan:

Wajib Pajak "A" membeli tanah dan bangunan dengan:

Nilai Perolehan Objek Pajak

Nilai Perolehan Objek Pajak Tidak Kena Pajak

$$
=\mathrm{Rp} 411.500 .000,00
$$

Nilai Perolehan Objek Pajak Kena Pajak

$$
=\text { Rp60.000.000,00 (-) }
$$

$$
=\operatorname{Rp} 351.500 .000,00
$$

Pajak Yang Terutang $=5 \% \times \mathrm{Rp} 351.000 .000,00$

$$
=\mathrm{Rp} 17.575 .000,00
$$

Setelah dilakukan perbandingan, ternyata terjadi ketidakpastian orientasi dari kepastian hukum dimana ada perbedaan nilai mencolok sehingga membuat orang mencari yang lebih menguntungkan. Jika masyarakat pada umumnya dengan luasan tanah terbatas tentu hal itu tidaklah perlu dipersoalkan menjadi besar, Namun jika penguasaan tanah berskala besar maka akan terjadi perhitungan yang diadakan dengan nilai perolehan rendah bahkan akan terjadi pemecahan kepemilikan hak mengatas 
namakan orang lain dan terjadi jual beli dibawah meja atau tertahan hanya sebatas perjanjian dua pihak.

Kembali pada tata perhitungan, bahwa perhitungan BPHTB yang menggunakan pilihan harga transaksi atau nilai pasar jauh lebih diminati ketimbang menggunakan NJOP PBB kecuali tarif BPHTB yang ditetapkan dalam suatu Peraturan Daerah sama dengan tarif PBB misal PBB adalah $0,2 \%$ dan BPHTB juga 0,2\% maka orang akan memililih tata perhitungan BPHTB tetapi hal itu tidak mungkin terjadi karena ambang batas maksimal 5\% daerah akan mengambil margin terendah kemungkinannya adalah $2 \%$ dan itu jelas akan bernilai tinggi ketimbang tarif PBB.

Pada intinya orang cenderung menggunakan tata perhitungan harga transaksi atau nilai pasar yang bisa di rekayasa ketimbang menggunakan NJOP PBB. Dari sinilah muncul peran dari Notaris/PPAT melibatkan diri untuk mengatur transaksi ulang mendekati Nilai Perolehan Objek Pajak Tidak Kena Pajak akibat dari pembuat Undang-Undang seperti menggunakan pengandaian bukan suatu kepastian. Dari itu banyak kalangan menilai bahwa perhitungan BPHTB yang ambigu itu memang menguntungkan bagi penguasaan tanah oleh golongan atau kelompok tertentu walaupun ada pembatasan kepemilikan sebagaimana ketentuan Pasal 7 Undang-Undang Nomor 5 Tahun 1960 tentang Pokok-Pokok Agraria yang menyatakan: "Untuk tidak merugikan kepentingan umum maka pemilikan dan penguasaan tanah yang melampaui batas tidak diperkenankan." ${ }^{28}$ Aturan pembatasan tersebut senyatanya menjadi wilayah abu-abu dengan adanya aturan lain yang mengeleminasinya.

Berhadapan dengan adanya ambiguitas norma untuk menetapkan besaran pajak terhutang BPHTB, memastikan bahwa sebagaimana teori kepastian orientasi dari kepastian hukum yang oleh Zippelius tidak lain adalah bentuk pengandaian dari kepastian hukum memang ambiguitas dalam penetapan besaran pajak terutang BPHTB apakah menggunakan harga transaksi atau nilai pasar dan apabila keduanya tidak diketahui maka menggunakan NJOP adalah suatu bentuk pengandaian semata. Kenapa

${ }^{28}$ Lembaran Negara Republik Indonesia Tahun 1960 Nomor 104. Dalam penjelasan: Azas yang menegaskan dilarangnya "groot-grondbezit" sebagai yang telah diuraikan dalam Penjelasan Umum (II angka 7). Soal pembatasan itu diatur lebih lanjut dalam pasal 17. Terhadap azas ini tidak ada pengecualiannya. Tambahan Lembaran Negara Nomor 2043. Lihat pula: Harsono, Boedi, 2005, Hukum Agraria Indonesia, Sejarah Pembentukan Undang-Undang Pokok Agraria, Isi dan Pelaksanaannya, (Cet. 10), Jakarta: Djambatan, h. 368. Landreform UUPA melarang pemilikan dan penguasaan tanah melampaui batas, dengan tujuan mencegah dan mengakhiri bertumpuknya tanah ditangan golongan-golongan dan orang-orang tertentu. Lihat pula Pasal 3 Peraturan Menteri Agraria Kepala Badan Pertanahan Nasional Nomor 18 Tahun 2016 tentang Pengendalian Penguasaan Tanah Pertanian. 
dikatakan pengandaian, statemen ini dikemukakan atas sebab: NJOPnya adalah NJOP PBB yang berada dalam ranah pengaturan berbeda, sedang BPHTB memiliki ranah tersendiri, jadi pengamanan oleh pembuat UndangUndang dengan menggunakan NJOP PBB adalah sesuatu yang tidak relevan dan menimbulkan ketidaktegasan Undang-Undang.

Ketidaktegasan Undang-Undang dimaksud melahirkan hukum tentang BPHTB yang tidak jelas dan a contrario dari teori bahwa hukum harus sedemikian jelas sehingga masyarakat dapat berpedoman kepadanya tanpa ada keragu-raguan tentang tindakan apa yang semestinya seperti yang dikatakan Zippelius dalam teorinya. Selain itu tata perhitungan yang rumit telah menjadikan kesulitan pula dalam memberikan informasi kepada publik rerata kelas menengah kebawah, sedang publik kelas atas sudah paham dengan aturan main BPHTB dimana mereka memanfaatkan ketidaktegasan aturan hukum untuk mendapatkan keuntungan besar.

Dari uraian diatas dapatlah dikonklusikan bahwa isi dari UUPDRD mengandung pertentangan dengan teori perpajakan "Perlindungan terhadap harta benda yang lebih banyak hartanya daripada harta si miskin, diharuskan pembayaran pajak yang lebih besar pula." Kenyataan menunjukkan lain, dimana pemilik harta benda yang lebih banyak diberi kesempatan untuk menyamakan kewajiban dengan yang memiliki harta sedikit. Artinya tidak ada pembagian beban pajak itu secara riel padahal berdasarkan teori pajak yang disebut teori "gaya pikul" perlindungan terhadap harta benda golongan kaya lebih berat memberikan beban kepada negara ketimbang si miskin maka selayaknyalah bahwa biaya-biaya yang dikeluarkan negara untuk menunaikan kewajibannya dibebankan kepada mereka itu.

Ketidaktegasan aturan dengan adanya pilihan menggunakan harga transaksi/nilai pasar atau NJOP PBB yang jelas orang akan memilih yang memberikan keuntungan melahirkan bentuk Self Assesment dalam BPHTB. Muncul asumsi ketika Peraturan Daerah memuat norma bahwa BPHTB menggunakan self assesment orang banyak curiga "jangan-jangan kelompok besar sangat diuntungkan dengan aturan semacam itu. Self assesment ${ }^{29}$ dapat dinilai tidak searah dengan teori kewajiban pajak mutlak dan bakti yang mengajarkan paham Organische Staatsleer. Semestinya berdasarkan teori pajak mutlak dan bakti negara berada dalam posisi kuat terhadap kelompok kaya dan memberikan keringanan bagi posisi si miskin. Menyitir dari apa yang dikatakan oleh W.H. Van de Berge, bahwa "Negara sebagai groepsverband (organisasi dari golongan) kenyataannya tidak memperhatikan pada syarat-syarat keadilan dalam menetapkan aturan pajak.

${ }^{29}$ Wajib Pajak diberikan kepercayaan untuk menghitung, memperhitungkan, membayar dan melaporkan sendiri pajak yang terutang dengan menggunakan SPTPD. 


\section{A. Eksistensi PPAT/Notaris dalam Kewajiban BPHTB}

Hal penting untuk diketahui di awal pembahasan ini tentang PPAT dan Notaris, disebabkan banyak kalangan teralienasi persoalan ini. Kunci jawabannya terdapat pada Pasal 6 ayat (1) huruf f, g, dan h Peraturan Pemerintah Nomor 24 Tahun 2016 tentang Perubahan Atas Peraturan Pemerintah Nomor 37 Tahun 1998 tentang Peraturan Jabatan Penjabat Pembuat Akta Tanah. Ketentuan Pasal 6 ayat (1) huruf huruf f, g, dan h, menyatakan:

"f. berijazah sarjana hukum "dan" lulusan jenjang strata dua kenotariatan "atau" lulusan program pendidikan khusus PPAT yang diselenggarakan oleh kementerian yang menyelenggarakan urusan pemerintahan agraria/pertanahan;

g. Lulus ujian yang diselenggarakan oleh kementerian yang menyelenggarakan urusan pemerintahan di bidang agraria/ pertanahan; dan

h. telah menjalani magang atau nyata-nyata telah bekerja sebagai karyawan pada kantor PPAT paling sedikit 1 (satu) tahun, setelah lulus pendidikan kenotariatan." 30

Apabila mencermati ketentuan Pasal 1 angka (1) Undang-Undang Nomor 2 Tahun 2014 tentang Perubahan Atas Undang-Undang Nomor 30 Tahun 2004 tentang Jabatan Notaris Jo Pasal 1 angka (1) Pemerintah Nomor 24 Tahun 2016 tentang Perubahan Atas Peraturan Pemerintah Nomor 37 Tahun 1998 tentang Peraturan Jabatan Pejabat Pembuat Akta Tanah, untuk memudahkan memahaminya, penulis muat dalam tabel berikut ini:

\section{Tabel. 2}

\section{Definisi Notaris dan PPAT}

\begin{tabular}{|l|l|}
\hline UU Nomor 2 Tahun 2014 & \multicolumn{1}{|c|}{$\begin{array}{c}\text { Pemerintah Pemerintah } \\
\text { Nomor 24 Tahun 2016 }\end{array}$} \\
\hline $\begin{array}{l}\text { Pasal 1 angka 1 } \\
\text { Notaris adalah pejabat umum } \\
\text { yang berwenang untuk } \\
\text { membuat akta autentik dan } \\
\text { memiliki kewenangan lainnya } \\
\begin{array}{l}\text { sebagaimana dimaksud dalam } \\
\text { Undang-Undang ini atau } \\
\text { berdasarkan undang-undang } \\
\text { lainnya." }\end{array}\end{array}$ & $\begin{array}{l}\text { Pejabat Pembuat Akta Tanah, selanjutnya } \\
\text { disebut PPAT, adalah pejabat umum yang } \\
\text { diberi kewenangan untuk membuat akta-akta } \\
\text { otentik mengenai perbuatan hukum tertentu } \\
\text { mengenai hak atas tanah atau Hak Milik } \\
\text { Atas Satuan Rumah Susun. }\end{array}$ \\
\hline
\end{tabular}

Sumber: Lembaran Negara Republik Indonesia Tahun 2014 Nomor 3 dan Lembaran Negara Republik Indonesia Tahun 2016 Nomor 120

${ }^{30}$ Lembaran Negara Republik Indonesia Tahun 2016 Nomor 120. 
Dari dua produk hukum di atas, satu merupakan Undang-Undang dan satu merupakan Peraturan Pelaksanaan dapat dipahami bahwa PPAT adalah Notaris. Hal itu telah dinormakan melalui ketentuan Pasal 6 ayat (1) huruf huruf f, g, dan h Pemerintah Pemerintah Nomor 24 Tahun 2016..., sebagaimana telah dikemukakan diawal. Dengan demikian sudah jelas kedudukan PPAT adalah Notaris selain yang dimaksudkan dari penggunaan kata "atau"31 Lulusan program pendidikan khusus PPAT yang diselenggarakan oleh kementerian yang menyelenggarakan urusan pemerintahan agraria/pertanahan. Konklusinya: PPAT jelas Notaris, sedang Notaris belum merupakan PPAT jika tidak mengikuti dan lulus ujian PPAT dan menyelesaikan program magang. Tafsiran ini dapat dianalisis melalui Pasal 17 huruf g Undang-Undang Nomor 24 Tahun 2016..., perihal larangan bagi Notaris "merangkap jabatan sebagai Pejabat Pembuat Akta Tanah dan/atau Pejabat Lelang Kelas II di luar tempat kedudukan Notaris".

Beralih dari analisis tentang regresi, kepada eksistensi PPAT/Notaris ${ }^{32}$. Mengacu pada Peraturan Pemerintah Nomor 24 Tahun 1997 tentang Pendaftaran Tanah. Pasal 37 ayat (1) menyatakan:

"Peralihan hak atas tanah dan hak milik atas satuan rumah susun melalui jual-beli, tukar menukar, hibah, pemasukan data perusahaan dan perbuatan hukum pemindahan hak lainnya, kecuali pemindahan hak melalui lelang hanya dapat didaftarkan jika dibuktikan dengan akta yang dibuat oleh PPAT yang berwenang menurut ketentuan peraturan perundang-undangan yang berlaku." 33

Kemudian, mengacu pula pada UUPDRD, Pasal 91 ayat (1) menyatakan: "Pejabat Pembuat Akta Tanah/Notaris hanya dapat menandatangani akta pemindahan Hak atas Tanah dan/atau Bangunan setelah Wajib Pajak menyerahkan bukti pembayaran pajak." ${ }^{34}$ Artinya pembayaran pajak BPHTB menjadi syarat "mutlak" bagi PPAT/Notaris untuk menyelesaikan peralihan hak atas tanah dan/atau bangunan. Perlawanan terhadap ketentuan Pasal 91 ayat (1) oleh UUPDR ditentukan melalui Pasal 93 ayat (1) yang menyatakan:

${ }^{31}$ Penggunaan kata "atau" merupakan presisi alternatif, sehingga tafsirannya jelas ada perbedaan dengan yang disebutkan di awal. Artinya ada jalur tersendiri. Namun realitasnya yang ada berupa ujian. Kemungkinannya ini perlu diperdebatkan lebih jauh dalam suatu kajian tersendiri.

${ }^{32}$ Seorang notaris juga sebagai pejabat pembuat akta tanah, tetapi ini tidak berarti setiap notaris adalah juga pejabat pembuat akta tanah karena kedua jabatan tersebut adalah jabatan yang berdiri sendiri dan kebetulan dijabat oleh orang yang sama.

${ }^{33}$ Lembaran Negara Republik Indonesia Tahun 1997 Nomor 59. Lihat pula: Harsono, Budi, Op. Cit., h. 538-539

${ }^{34}$ Lembaran Negara Republik Indonesia Tahun 2009 Nomor 130. 
"Pejabat Pembuat Akta Tanah/Notaris dan kepala kantor yang membidangi pelayanan lelang negara, yang melanggar ketentuan sebagaimana dimaksud dalam Pasal 91 ayat (1) dan ayat (2) dikenakan sanksi administratif berupa denda sebesar Rp7.500.000,00 (tujuh juta lima ratus ribu rupiah) untuk setiap pelanggaran." 35

Setelah dilakukan pengacuan, dimunculkan pertanyaan: Apakah tindakan menurunkan harga transaksi jual beli berdasar arahan PPAT/Notaris dapat menimbulkan akibat hukum di kemudian hari? Pertanyaan tersebut mengandung makna adanya tindakan mengarahkan oleh PPAT/Notaris kepada para pihak untuk menurunkan harga jual beli dengan maksud mendekati nilai perolehan objek pajak tidak kena pajak. Hal itu biasanya terjadi hanya pada lingkup peralihan hak atas tanah dengan jenis "jual beli" dimana harga transaksi awal yang besar dapat memberatkan kepada pihak pembeli untuk membayar BPHTB menjadi besar dan bisa menjadi batal sehingga PPAT/Notaris juga batal menerima pembayaran.

Apabila mencermati tentang berapa perolehan uang jasa PPAT/Notaris, mengacu pada Pasal 36 Undang-Undang Nomor 30 Tahun 2004 tentang Jabatan Notaris, menyatakan:

"(1) Notaris berhak menerima honorarium atas jasa hukum yang diberikan sesuai dengan kewenangannya.

(2) Besarnya honorarium yang diterima oleh Notaris didasarkan pada nilai ekonomis dan nilai sosiologis dari setiap akta yang dibuatnya.

(3) Nilai ekonomis sebagaimana dimaksud pada ayat (2) ditentukan dari objek setiap akta sebagai berikut:

a. sampai dengan Rp100.000.000,00 (seratus juta rupiah) atau ekuivalen gram emas ketika itu, honorarium yang diterima paling besar adalah 2,5\% (dua koma lima persen);

b. di atas Rp100.000.000,00 (seratus juta rupiah) sampai dengan Rp1.000.000.000,00 (satu miliar rupiah) honorarium yang diterima paling besar 1,5\% (satu koma lima persen); atau

c. di atas Rp1.000.000.000,00 (satu miliar rupiah) honorarium yang diterima didasarkan pada kesepakatan antara Notaris dengan para pihak, tetapi tidak melebihi $1 \%$ (satu persen) dari objek yang dibuatkan aktanya.

(4) Nilai sosiologis ditentukan berdasarkan fungsi sosial dari objek setiap akta dengan honorarium yang diterima paling besar Rp5.000.000,00 (lima juta rupiah). ${ }^{, 36}$

\footnotetext{
${ }^{35}$ Loc. Cit.

${ }^{36}$ Lembaran Negara Republik Indonesia Tahun 2004 Nomor 117.
} 
Berdasarkan pencermatan, kalau saja PPAT/Notaris memang mengarahkan untuk menurunkan nilai jual beli, perolehan PPAT/Notaris tetap pada posisi $2,5 \%$ dari nilai harga transaksi setelah dikurangi nilai objek tidak kena pajak. Dari itu menarik bagi PPAT/Notaris ikut masuk kedalam pemberian nilai harga transaksi jual beli secara bebas. Setidaknya menurunkan beberapa poin untuk menguntungkan kepada pihak yang akan membayar BPHTB dan PPAT/Notaris mendapatkan tambahan bonus dari pihak yang akan membayar BPHTB dan setidaknya pula para pihak masih untung. ${ }^{37}$ Walaupun keadaan demikian mengandung sifat "bedrogen betekenis" yang direkayasa para pihak tetapi masih berada dalam wilayah abu-abu, karena UUPDRD sendiri tegas memberikan ruang pilihan bagi wajib pajak BPHTB dengan memilih yang menguntungkan (lex certa). Bagi PPAT/Notaris terlepas dari persoalan kode etik karena tidak mengadakan sesuatu yan baru selain yang tertulis (lex scripta), dikuatkan bahwa konsekuensi logis dari lex certa dan lex scripta Pasal 87 ayat (2) dan ayat (3) UUPDRD.

Konsekuensi logis dimaksud tidak lain adalah melahirkan interpretasi gramatikal Lex Stricta, bahwa: aturan yang memberikan keuntungan kepada orang lain tidak dibenarkan untuk mengadakan yang baru selain dari yang tertulis dalam aturan tersebut. (tidak dapat diinterpretasi yang lain dari apa yang tertulis). Hal ini yang oleh PPAT/Notaris bukanlah suatu ancaman bagi profesi atau disebut dengan tindakan malpraktik PPAT/Notaris. ${ }^{38}$ Disini PPAT/Notaris memainkan perannya sesuai dengan prinsip hukum walaupun aturan hukumnya salah. Artinya tidak dapat dipersalahkan, karena memang dalam pengaturan

\footnotetext{
${ }^{37}$ Kekhawatiran muncul jika jual beli itu tanpa sepengetahuan PPAT/Notaris belum dilunasi atau secara sembunyi antar penjual dan pembeli, misal disepakati seharga Rp.200.000.000,- telah dibayar separo karena pembeli ingin mengagunkan sertifikat itu atas namanya dan berjanji apabila pencairan bank terlaksana baru akan melunasi kepada penjual, sedang untuk akta perolehan dihadapan notaris sudah menyatakan lunas dan terjadi perolehan hak atas tanah dengan menurunkan harga menjadi 100 juta untuk maksud mengurangi dasar pengenaan BPHTB dibuatlah kuitansi kedua yang sah dihadapan notaris sebesar itu, dikemudian hari pembeli tidak juga membayar karena sudah merasa sesuai harga kuitansi, apakah hal ini tidak menimbulkan permasalahan hukum baru.

${ }^{38}$ Malpraktik PPAT/Notaris mencakup bentuk-bentuk pengingkaran atau penyimpangan atau kurangnya kemampuan dari tugas dan tanggung jawab notaris atau pejabat pembuat akta tanah baik karena kesalahan atau kelalaian yang dapat dipertanggungjawabkan kepada mereka untuk melaksanakan kewajiban-kewajiban professional atau yang didasarkan kepada kepercayaan. Pada jabatan PPAT/Notaris, malpraktek yang dilakukan ini dapat terjadi dalam bidang etik dan hukum, baik hukum pidana, perdata maupun administrasi.
} 
BPHTB fungsi mereka hanya akan selesai kalau wajib pajak melakukan pembayaran pajak terutangnya. Jika tidak, para PPAT/Notaris tidak dapat memperoleh inkam. Namun apabila memperhatikan pada ketentuan Undang-Undang Nomor 30 Tahun 2004 tentang Jabatan Notaris sebagaimana diubah dengan Undang-Undang Nomor 02 Tahun 2014 tentang Perubahan Atas Undang-Undang Nomor 30 Tahun 2004 tentang Jabatan Notaris, diketahui beberapa hal berikut ini:

a. Notaris berwenang membuat akta yang berkaitan dengan pertanahan (Vide: Pasal 15 ayat (2) huruf f);

b. Dalam menjalankan jabatannya, Notaris berkewajiban bertindak amanah, jujur, saksama, mandiri, tidak berpihak, dan menjaga kepentingan pihak yang terkait dalam perbuatan hukum (Vide: Pasal 16 ayat (1) huruf a);

Apabila mengacu pada Pasal 16 ayat (1) huruf a, dalam eskalasi BPHTB, dapat dipahami bahwa PPAT/Notaris tidak dapat dikatakan melawan aturan itu sepenuhnya dan hanya pada soal "jujur" yang sangat limitatif untuk dikenakan pelanggaran kejujuran bahkan mendekati "nihil" akibat dari Pasal 15 ayat (1) Undang-Undang Nomor 2 Tahun 2014 tentang Jabatan Notaris sendiri membuat ketentuan yang mengamankan kewenangan Notaris. Beda bila mengacu pada Pasal 15 ayat (1) sebelum perubahan yakni Undang-Undang Nomor 30 Tahun 2004 tentang Jabatan Notaris. Untuk memastikannya perhatikan apa yang dirubah dari ketentuan Pasal 15 ayat (1), untuk memudahkan memahaminya penulis kemukakan dalam tabel berikut ini:

Tabel. 3

Kewenangan Utama Notaris

\begin{tabular}{|l|l|}
\hline UU Nomor 30 Tahun 2004 & \multicolumn{1}{|c|}{ UU Nomor 2 Tahun 2014 } \\
\hline $\begin{array}{l}\text { Notaris berwenang membuat akta } \\
\text { otentik mengenai semua perbuatan, } \\
\text { perjanjian, dan ketetapan yang } \\
\text { diharuskan oleh peraturan } \\
\text { perundang-undangan dan/atau yang }\end{array}$ & $\begin{array}{l}\text { Notaris berwenang membuat akta otentik } \\
\text { mengenai semua perbuatan, perjanjian, } \\
\text { dan penetapan yang diharuskan oleh } \\
\text { peraturan perundang-undangan dan/ atau } \\
\text { dikehendaki oleh yang ber- } \\
\text { kepentingan untuk dinyatakan } \\
\text { berkepentingan untuk dinyatakan dalam } \\
\text { dalam akta otentik, menjamin kepastian tanggal } \\
\text { kepastian tanggal pembuatan akta, } \\
\text { menyimpan akta, mem-berikan } \\
\text { grosse, salinan dan kutipan akta, } \\
\text { semuanya itu sepanjang pembuatan } \\
\text { akta-akta itu tidak juga ditugaskan } \\
\text { akta, semuanya itu sepanjang pem- } \\
\text { buatan akta-akta itu tidak juga } \\
\text { ditugaskan atau dikecualikan kepada } \\
\text { pejabat lain atau orang lain yang } \\
\text { lain atau orang lain yang ditetapkan } \\
\text { oleh undang-undang. }\end{array}$ \\
\hline
\end{tabular}


Sumber: Lembaran Negara Republik Indonesia Tahun 2004 Nomor 117 dan Lembaran Negara Republik Indonesia Tahun 2014 Nomor 3

Dari tabel di atas, antara ketetapan dan penetapan menjadi masalah sehingga dilakukan perubahan, menimbulkan pertanyaan hal ihwal apa mesti dirubah hanya untuk satu kata. Kontekstual dengan BPHTB sangatlah urgen, bisa jadi karena motif ini terjadi perubahan, perhatikan:

1. Notaris berwenang membuat, ... ketetapan yang diharuskan oleh peraturan perundang-undangan dan/atau yang dikehendaki oleh yang berkepentingan untuk dinyatakan dalam akta otentik;

2. Notaris berwenang membuat, ... penetapan yang diharuskan oleh peraturan perundang-undangan dan/atau yang dikehendaki oleh yang berkepentingan untuk dinyatakan dalam akta otentik;

Setelah diperhatikan antara "ketetapan" dan "penetapan", sifatnya redaksional. Jika "ketetapan" jelas PPAT/Notaris terbelenggu apalagi terkait dengan BPHTB, awalan "ke" menjumbuhkan sudah baku atau sudah ditetapkan lebih awal sedang BPHTB tidaklah ketetapan melainkan penetapan.

Dari eskalasi Pasal 15 ayat (1) dirumuskan anasirnya bahwa "Notaris berwenang membuat "penetapan" yang dikehendaki oleh yang berkepentingan untuk dinyatakan dalam akta otentik. Akta otentik itu sendiri adalah akta jual beli tanah dan/atau bangunan dimana para pihak berkehendak diturunkan nilai jual belinya untuk menghindari tingginya BPHTB dan tentunya itu bisa berasal dari penawaran PPAT/Notaris atau inisiatif para pihak sendiri. ${ }^{39}$ Dengan demikian sangat sulit mengikat persoalan ini kedalam rumusan Pasal yang menjeratnya sebagai pelanggaran. Dari pada itu ketentuan Pasal 85 tentang sanksi bagi Notaris dalam Undang-Undang Nomor 30 Tahun 2004 tentang Jabatan Notaris tidak terpenuhi unsur untuk menjatuhkan sanksi pelanggaran terhadap ketentuan Pasal 16 ayat (1) huruf a tentang kewajiban bertindak amanah, jujur, saksama, mandiri, tidak berpihak, dan menjaga kepentingan pihak yang terkait dalam perbuatan hukum. Karena materinya memang menjaga kepentingan para pihak terkait dan tidak ada ketentuan untuk berpihak pada aturan hukum negara sedang aturan hukum negara sendiri bersifat ambigu.

Akhir dari uraian ini, bahwa persoalan eksistensi PPAT/Notaris yang terlibat dalam menurunkan harga transaksi jual beli tanah dan/atau

\footnotetext{
${ }^{39}$ Sebagaimana Susani dan Herma berpandangan: setiap pelaksana atau pemangku profesi hukum juga mempunyai hubungan kepentingan dengan baragam orang atau pihak. Salah satu pelaksana profesi hukum ini adalah notaris. Dalam: Susani Triwahyuningsih dan Herma Yusti, 2020. Kekuatan Memaksa Norma Yuridis Sebagai Upaya Menjaga Kewibawaan Profesi Notaris. Jurnal Hukum dan Kenotariatan, Vol. 4 No. 2 Agustus, h. 273.
} 
bangunan untuk menurunkan besaran BPHTB yang dibayar wajib pajak tidak menimbulkan akibat hukum karena aturan UUPDRD tidak tegas menjatuhkan dasar pengenaan tarif BPHTB, sedang dalam aturan UndangUndang tentang PPAT/Notaris sendiri memberikan pengamanan bagi PPAT/Notaris dan tidak pula ada sanksi yang dapat dijatuhkan karena memang tidak ada aturan hukum melarangnya. Intisarinya bahwa politik hukum pembentukan suatu Undang-Undang sangat kental dengan berbagai kepentingan yang saling mengamankan wilayahnya. UUPDRD yang nuansanya memberikan pengamanan dan keuntungan bagi golongan atau kelompok yang kuat dalam penguasaan tanah dan Undang-Undang Pejabat Notaris pun juga mengamankan kedudukan PPAT/Notaris (Positivistik).

\section{KESIMPULAN}

Hubungan antara BPHTB dengan informasi publik tidaklah dapat dipisahkan, karena sifat dasarnya adalah peran aktif dari masyarakat untuk turut serta membangun daerah melalui pajak yang dibayarkannya. BPHTB terkait dengan informasi publik, masuknya kedalam kategori informasi yang wajib tersedia setiap saat, dimana secara definisi memiliki pengertian "adalah informasi yang harus disediakan oleh Badan Publik dan siap tersedia untuk bisa langsung diberikan kepada Pemohon Informasi Publik ketika terdapat permohonan terhadap Informasi Publik tersebut". Disinilah ternyata problem BPHTB tidak diinformasikan kepada publik, sifatnya hanya akan diberikan atas permohonan dari yang berkepentingan sehingga BPHTB menjadi tidak familiar dalam pengetahuan publik. Dalam eskalasi informasi BPHTB ada kemungkinan keenganan pejabat publik menginformasikan secara detail bagaimana perolehan nilai objek pajaknya disebabkan kerumitan tata cara perhitungan sehingga sulit melakukan penyederhanaan bahasa, hal itu menjadi suatu tantangan yang perlu diatasi Badan Publik dalam menyampaikan informasi kepada masyarakat.

Dalam menetapkan besaran pajak terhutang BPHTB, memang terjadi ketidakpastian orientasi dari kepastian hukum karena ambiguitas dalam penetapan besaran pajak terutang BPHTB, apakah menggunakan harga transaksi atau nilai pasar dan apabila keduanya tidak diketahui maka menggunakan NJOP adalah suatu bentuk pengandaian semata. Kenapa dikatakan pengandaian, statemen ini dikemukakan atas sebab: NJOPnya adalah NJOP PBB yang berada dalam ranah pengaturan berbeda, sedang BPHTB memiliki ranah tersendiri, jadi pengamanan oleh pembuat UndangUndang dengan menggunakan NJOP PBB adalah sesuatu yang tidak relevan dan menimbulkan ketidaktegasan Undang-Undang. Ketika hukumnya tidak jelas yang muncul adalah a contrario, dimana isi dari UUPDRD mengandung pertentangan dengan teori perpajakan "Perlindungan terhadap 
harta benda yang lebih banyak hartanya daripada harta si miskin, diharuskan pembayaran pajak yang lebih besar pula." Kenyataan menunjukkan lain, dimana pemilik harta benda yang lebih banyak diberi kesempatan untuk menyamakan kewajiban dengan yang memiliki harta sedikit. Artinya tidak ada pembagian beban pajak itu secara riel padahal berdasarkan teori pajak yang disebut teori "gaya pikul" perlindungan terhadap harta benda golongan kaya lebih berat memberikan beban kepada negara ketimbang si miskin maka selayaknyalah bahwa biaya-biaya yang dikeluarkan negara untuk menunaikan kewajibannya dibebankan kepada mereka itu.

Terungkap atas dasar Pasal 15 ayat (1) Undang-Undang Nomor 02 Tahun 2014 tentang Perubahan Atas Undang-Undang Nomor 30 Tahun 2004 tentang Jabatan Notaris, dirumuskan anasirnya bahwa "Notaris berwenang membuat penetapan yang dikehendaki oleh yang berkepentingan untuk dinyatakan dalam akta otentik. Akta otentik itu sendiri adalah akta jual beli tanah dan/atau bangunan dimana para pihak berkehendak diturunkan nilai jual belinya untuk menghindari tingginya BPHTB dan tentunya itu bisa berasal dari penawaran PPAT/Notaris atau inisiatif para pihak sendiri. Dengan demikian persoalan eksistensi PPAT/Notaris yang terlibat dalam menurunkan harga transaksi jual beli tanah dan/atau bangunan untuk menurunkan besaran BPHTB yang dibayar wajib pajak tidak menimbulkan akibat hukum karena aturan UUPDRD tidak tegas menjatuhkan dasar pengenaan tarif BPHTB, sedang dalam aturan UndangUndang tentang PPAT/Notaris sendiri memberikan pengamanan bagi PPAT/Notaris dan tidak pula ada sanksi yang dapat dijatuhkan karena memang tidak ada aturan hukum melarangnya.

\section{SARAN}

1. Sesuai dengan kewenangan, Pemerintah Daerah Kabupaten/Kota wajib menyampaikan informasi ke publik tentang BPHTB khususnya tata perhitungan besaran nilai yang harus dibayar oleh wajib pajak. Apapun tingkat kerumitannya setidaknya Pemerintah Daerah memenuhi kewajibannya.

2. Pengaturan BPHTB khususnya tentang penetapan tarifnya harus tegas dan tidak menciptakan pilihan yang menimbulkan regresi, daripada itu diperlukan pembenahan aturan ke depan yakni Pasal 87 terkait dengan Nilai Perolehan Objek Pajak.

3. Dengan tingkat kerumitan, disatu sisi Pemerintah Daerah memerlukan peningkatan Pendapatan Asli Daerah di sektor perpajakan yang berada dalam kewenangannya, dalam konteks ini BPHTB menempati kedudukan potensial tetapi tertekan akibat kecenderungan penggunaan harga transaksi. Pada sisi lainnya Pemerintah Daerah sendiri tidak 
melakukan pengawasan atas harga-harga transaksi dibawah NJOP dan tidak ada perangkat daerah yang berperan mengawasinya. Solusinya untuk perhitungan BPHTB Pemerintah Daerah membangun sistem dan aparatur pelaksana perhitungan sehingga tidak langsung kepada PPAT/Notaris namun konsekuensinya tidak memberlakukan self assesment pada BPHTB.

\section{DAFTAR PUSTAKA}

\section{Buku}

Alamsyah Saragih, Pengecualian Informasi di Badan Publik Negara, Jakarta: Komisi Informasi Pusat, 2012.

Boedi Harsono, Hukum Agraria Indonesia, Sejarah Pembentukan UndangUndang Pokok Agraria, Isi dan Pelaksanaannya, Jakarta: Djambatan, 2005.

Franz Magnis Suseno, Etika Politik (Prinsip-Prinsip Moral Dasar Kenegaraan Modern), Jakarta: PT. Gramedia Pustaka, 2003.

Indonesian Center For Environmental Law. (tt) Modul Bagi Badan Publik. Melaksanakan Undang-Undang Nomor 14 Tahun 2008 Tentang Keterbukaan Informasi Publik.

Rochmat Soemitro, Pajak dan Pembangunan, Bandung: Eresco, 1974.

R. Santoso Brotodihardjo, Pengantar Ilmu Hukum Pajak, Bandung: PT. Refika Aditama, 2003.

Wiratni Ahmadi, Perlindungan Hukum Bagi Wajib Pajak Dalam Penyelesaian Sengketa Pajak, Bandung: PT. Refika Aditama, 2006.

Susani Triwahyuningsih dan Herma Yusti, 2020. Kekuatan Memaksa Norma Yuridis Sebagai Upaya Menjaga Kewibawaan Profesi Notaris. Jurnal Hukum dan Kenotariatan, Vol. 4 No. 2 Agustus

\section{Internet}

Open Government Partnership, Participating Countries, http://www.opengovpartnership.org/countries.

Good Law \& Practice, 2012, “ Access to Information Laws: Overview and Statutory Goals", http://right2info.org/access-to-information-laws. 